Volume 6 Issue 2, September 2021:pp. 199 - 212 Copyright @ LamLaj. Faculty of Law, Lambung Mangkurat University, Banjarmasin, South Kalimantan, Indonesia. ISSN: 2502-3136 | e-ISSN: 2502-3128.

Open Access at: http://lamlaj.ulm.ac.id/web/

\title{
DISPUTE SETTLEMENT ANALYSIS AND REFUSED CLAIMS IN PAYMENT GATEWAY TRANSACTIONS ON PAYPAL INDONESIA
}

\author{
Recca Ayu Hapsari ${ }^{1}$, Bambang Hartono ${ }^{2}$, Yana Listiyani ${ }^{3}$ \\ Faculty of Law, University of Bandar Lampung \\ Jl. Soekarno Hatta No.1, Way Dadi, Lampung, Indonesia35132 \\ Email : recca@ubl.ac.id \\ Faculty of Law, University of Bandar Lampung \\ Jl. Soekarno Hatta No.1, Way Dadi, Lampung, Indonesia35132 \\ Email : Bambang.hartono@ubl.ac.id \\ Faculty of Law, University of Bandar Lampung \\ J. Soekarno Hatta No.1, Way Dadi, Lampung, Indonesia35132 \\ Email :yanalisti27@gmail.com
}

Submitted : 06/06/2021 Reviewed: 31/08/2021 Accepted:11/09/2021

\begin{abstract}
In transactions using Paypal, of course, there are many reasons for the risk of disputes occurring, ranging from delays in delivery, damaged goods, and transactions without authorization. The problem will be different when they carry out business transactions in different regions of the country and they have different nationalities. The research method uses a normative and empirical juridical approach, a normative juridical approach is carried out by studying legal norms or rules, while the empirical approach is carried out by direct interviews with sources who will relate to research problems, the data analysis used is qualitative. In trading transactions via the internet, trade is generally carried out by people who are located and subject to different countries and jurisdictions The legal relationship between Payment Gateway Users and Payment Gateway Providers At Fintech Paypal Indonesia is where the parties involved in the electronic payment system include consumers, business actors, acquirers, issuers and payment gateway providers. legal relationships that arise between consumers, business actors, acquirers, issuers and payment gateway operators are born from agreements made by the parties. Dispute Resolution and Chargeback Claims in Payment Gateway Transaction activities on Paypal Fintech where the paypal system provides services can communicate directly with the seller by opening a dispute at the Paypal Dispute Settlement Center. if it is not completed in following the policies provided by paypal services, consumers or business actors can ask for recommendations to mediate to the paypal service center but if they are not finished, business actors and consumers can resolve disputes through litigation, which usually business actors are subject to the applicable law, applies where the consumer is a national.
\end{abstract}

Keywords: dispute resolution; Fintech; Payment Gateway; Paypal

DOI: $10.32801 /$ lamlaj.v6i2.262 


\section{INTRODUCTION}

Technological developments play an important role in spurring world economic growth. One of the important roles of technological developments is to facilitate financial business transactions. One of the technologies currently developing in the business world is financial technology (fintech), which is a new breakthrough in the information technology era that can be a solution by collaborating between financial systems and technology..

The entry of fintech in Indonesia raises the opinion that the presence of fintech will change the world of conventional banking because it considers the fintech industry to provide many conveniences in financial services, so that people will be interested and switch from conventional banks. ${ }^{1}$ Because the development of information technology makes it easier to carry out fund transfers. The rapid development of fintech has made the digital financial system increasingly popular among the public. The public can now make payments to bills anywhere just by accessing the internet and not only consumers who are competing to use the digital financial system, but almost all business actors have switched to electronic trading services (e-commerce) through payment gateways. ${ }^{2}$

The use of electronic payment instruments is supported by the availability of credit card

\footnotetext{
1 Ayup Suran Ningsih, "Legal Review of Financial Technology Peer To Peer Lending Based on Indonesian Collateral Law Perspective," Substantive Justice International Journal of Law 3, no. 2 (2020): 109-124, https://substantivejustice.id/index.php/ sucila/article/view/73.

2 Suryansyah, "Legal Protection on Intellectual Property Rights in the Development of Creative Economy in Mamuju Regency," Substantive Justice International Journal of Law 2, no. 1 (2019): 54-70, https://substantivejustice.id/index.php/sucila/article/ view/30.
}

and debit card facilities. The payment system commonly used by businesses and consumers is to use Paypal services. Paypal is a virtual account that provides transfer services and online payments. ${ }^{3}$ PayPal is a platform from a United States company that has several branches in the country, one of the company's branches in Asia is located in Singapore, in this case PayPal acts as a third party whose function is as a payment medium in online buying and selling transactions to process transactions between business actors with consumers both PayPal accounts, bank accounts, credit cards and debit cards.

Citing the paypal page, getting to know paypal in the payment system, it is stated that Paypal user statistics worldwide currently operate in 202 countries and manage more than 232 million accounts, 300 million users globally, Paypal allows customers to send, receive and store funds in 25 Currencies around the world.

The act of buying and selling transactions carried out by business actors and consumers, even though they are carried out in cyberspace, has consequences in tangible forms, namely the consumer is obliged to pay and the business actor is obliged to deliver the goods. The law has regulated their relationship earlier as a form of legal relationship in the form of buying and selling. ${ }^{4}$

When making a paypal transaction, there are many things that must be considered to reduce the occurrence of failed payments, payments are withheld, goods that never ar-

\footnotetext{
3 Surohman et al., "Analisa Sentimen Terhadap Review Fintech Dengan Metode Naive Bayes Classifier Dan K- Nearest Neighbor," EVOLUSI: Jurnal Sains dan Manajemen 8, no. 1 (2020): 93-105, https://ejournal. bsi.ac.id/ejurnal/index.php/evolusi/article/view/7535.

4 Yudha Bhakti Ardhiwisastra, Penafsiran Dan Konstruksi Hukum (Bandung: Alumni, 2000), 34
} 
rive after the transaction or goods that arrive but are not in accordance with the order make the customer feel disadvantaged when transactions using paypal. If the legal relationship between business actors and consumers is carried out in the same territory of the country where they are in one jurisdiction then it does not cause significant legal problems, they are subject to the same legal provisions or they have the same nationality, it does not become a problem for them automatically, subject to the jurisdiction of their country.

The problem will be different when they carry out business transactions in different regions of the country and they have different nationalities. In trading transactions via the internet, trade is generally carried out by people who are located and subject to different countries and jurisdictions. Things like this create difficulties in determining which country's legal jurisdiction will be used in resolving disputes that occur in Payment Gateway transactions at Fintech Paypal Indonesia if one of the parties violates the contract or does not match the ordered goods obtained when buying through online sales that they have agreed to ? What is the legal relationship between consumers and payment gateway providers in online buying and selling transactions?

Based on the description of the background above, the author is interested in conducting research which is stated in the form of a proposal with the title: Dispute settlement analysis and refused claims in payment gateway transactions on paypal Indonesia.

\section{METHOD}

The research method uses a normative and empirical juridical approach, a normative juridical approach is carried out by studying legal norms or rules, while the empirical approach is carried out by direct interviews with sources who will relate to research problems, the data analysis used is qualitative.

Furthermore, secondary data in this study consisted of three (3) legal materials:

1) Primary Legal Materials

a. The 1945 Constitution of the Republic of Indonesia Amendments

b. Code of Civil law (Burgerlijk Wetboek (BW)/Code civil)

c. Law Number 8 of 1999 concerning Consumer Protection

d. Law Number 19 of 2016 concerning Amendments to Law Number 11 of 2008 concerning Information and Electronic Transactions (ITE Law)

e. Financial Services Authority Regulation Number 13 / POJK.02 / 2018 concerning Digital Financial Innovation in the Financial Services Sector

f. Bank Indonesia Regulation (PBI) Number 19/12 / PBI / 2017 Concerning the Implementation of Financial Technology (PBI 19/12)

The materials supporting this research are obtained from reading, citing, literature, literature studies related to research.

2) Tertiary Legal Materials

The supporting materials for this research were obtained from the internet / website, scientific writings related to research.

\section{ANALYSIS AND DISCUSSION Legal Relationship of Payment Gateway Users with Payment Gateway Operators at Fintech Paypal Indonesia}

A legal relationship is a relationship governed by law. Legal relations regulated by law are the rights and obligations of citizens, one individual to the citizen, another person in so- 
cial life. So, legal relations are the legal rights and obligations of every citizen or individual in social life. If these rights and obligations are not fulfilled, they can be subject to sanctions according to law. ${ }^{5}$

A legal relationship is an engagement born as a result of a legal event. Legal events occur because of laws and agreements. In the legal relationship of health services, legal relations have been regulated in various health law regulations in the form of laws and implementing regulations and are regulated based on a health service agreement between the Health Service Provider and the Health Service Provider. The contents of a legal relationship are reciprocal rights and obligations. One party has the right to demand something from the other party, and the other party is obliged to fulfill that demand, and vice versa.

Relationships that occur in electronic transactions are generally engagements born out of agreements or contracts which are generally regulated in Book III of the Second Chapter of the Civil Code. The legal relationship in the agreement is a legal relationship created by the parties in the agreement when they have agreed to bind themselves to each other. An agreement will protect the parties if it is made legally because it will determine the process of the next legal relationship. There are conditions that must be met for the validity of a contract which is contained in Article 1320 Civil Code, namely:

1. Agree on those who bind themselves;

2. The ability to make an engagement;

3. A certain thing;

\footnotetext{
Abdulkadir Muhammad, Hukum Perdata Indonesia (Bandung: Citra Aditya Bakti, 2017) ,45-48
}

\section{A permissible cause.}

Based on the results of an interview with the Lampung Consumer Protection Agency with Mr. Ansori, he stated that in the legal relationship between consumers and business actors there is a sale and purchase agreement regulated in Article 1457 of the Civil Code which states that buying and selling is an agreement between the seller and the buyer in which the seller is obliged to deliver an object and the buyer is obliged to pay the agreed price. Buying and selling transactions between consumers and business actors are carried out using internet media, so that they follow the provisions contained in Law Number 11 of 2008 concerning Information and Electronic Transactions as amended by Law Number 19 of 2019 concerning Amendments to Law Number 11 of 2008 concerning Information and Electronic Transactions (hereinafter referred to as UU ITE).

In addition, there are also agreements made between consumers and business actors related to payment transactions which in the agreement mention the use of websites owned by business actors as a payment mechanism and process for products that have been purchased on the business actor's website.

The legal relationship between the issuer and the consumer is stated in writing in an agreement in the form of a standard contract. The agreement contains the provision of credit on the basis of the rights of the loan-borrowing agreement. ${ }^{6}$ In the credit agreement, the issuer will make a payment in advance

\footnotetext{
${ }^{6}$ Sri Yunengsih Utama, "Perlindungan Hukum Terhadap Pemegang Kartu Kredit Sebagai Akibat Penyalahgunaan Kartu Kredit Dalam Transaksi Perdagangan" (Universitas Pasundan, 2013), http:// repository.unpas.ac.id/1712/.
} 
first for expenses made by consumers, and consumers are required to pay transactions to the issuer. ${ }^{7}$

According to the results of an interview with Ms. Triani Susanti from Bank Indonesia Regional Lampung, the agreement between the merchant and the acquirer created a legal relationship between the two. The agreement made is a business actor cooperation agreement (merchant agreement). The agreement stipulates that acquirers (Banks or Non-Bank Institutions that cooperate with traders, which can process electronic money data issued by other parties) provide services in the form of facilities in electronic transactions for business actors.

According to Article II letter D number 4 Circular Letter of Bank Indonesia No. 11/10/DASP concerning the Implementation of Card-Based Payment Instrument Activities Explains that the Issuer and acquirer enter into a cooperation made in an agreement containing the implementation of card-based payment instrument activities.

The agreement also contains a clause on the rights and obligations of the parties, the plan for implementing the cooperation, the period of cooperation as well as procedures and mechanisms for resolving disputes that may occur between the parties. Transactions that occur between payment gateway providers and business actors are business to business transactions, which is a business communication system between business actors or in other words online transactions. electronic inter-company (business actors) which

${ }^{7}$ Chaidar Shofi Rosul, "Hubungan Hukum Penyelenggara Payment Gateway Dan Konsumen Dalam Sistem Pembayaran Elektronik," JuristDiction 2, no. 5 (2019): 1611-1630, https://e-journal. unair.ac.id/JD/article/view/15220. is carried out routinely and internally large capacity or volume.

The results of research and interviews with Mr. Ansori from the Lampung Consumer Protection Institute stated that business actors in conducting transactions bind themselves in an agreement.

The legal relationship that occurs between payment gateway providers and merchants is an agreement to use electronic payment system services. Categorized as an agreement for the use of electronic payment system services because the payment gateway provider makes an offer in the form of internet transaction payment system services and business actors accept the offer by making achievements in the form of payments. There are also those who say that the form of agreement made between payment gateway providers and business actors is a cooperation agreement. The obligations and rights of payment gateway operators and business actors as parties can be seen in Paypal's Terms of Use.

The agreement states the rights and obligations of both payment gateway providers and business actors. The main obligation of payment gateway operators is to manage and maintain internet payment system transactions so that they remain smooth and operational. The obligations of the payment gateway operator are also rights that will be obtained by business actors, including providing information to business actors on the status of payment transactions, providing technical and operational support, providing internet transaction data reconciliation and preparing standard operational procedures. In addition, there are certain rights owned by payment gateway providers, among others, payment gateway providers have the right to limit, block and take necessary legal steps if 
the merchant is deemed to have committed a violation based on the agreed agreement or applicable law.

Business actors also have obligations as a result of the agreement, including making payments to payment gateway providers in every successful internet transaction, providing correct descriptions of goods and products, displaying transaction terms for consumers, storing transaction evidence and complying with other terms and conditions. ${ }^{8}$

The bank and the payment gateway operator enter into a cooperation agreement to process payments using a card (payment processing agreement). Payment gateway operators cooperate with banks with the status of acquirers and issuers. Acquirer is a bank or non-bank institution that cooperates with merchants in processing transactions from payment instruments using cards issued by parties other than the acquirer concerned and is responsible for the settlement of payments to merchants. Issuer or issuer is a bank or non-bank institution that issues payment instruments using cards. If you look back at the role of payment gateways, which are tasked with transmitting transaction data from merchants to acquirers, payment gateways as payment service providers provide payment processing services for certain transactions for merchants and transmit this information to acquirers. Then the acquirer will process the information in internet transactions.

Looking at the interaction scheme above, it can be seen that the cooperation that occurs between payment gateway providers and

\footnotetext{
${ }^{8}$ Prakas Dwi Rahardika, "Implementasi Sistem Pembayaran Dengan Payment Gateway Pada Pemesanan Tour \& Transport (Studi Kasus PT.Hanoman Pandu Wisata)" (Universitas Teknologi Yogyakarta, 2020), 2
}

acquirers is only limited to forwarding consumer data information from merchants' web browsers to acquirers and issuers.

Elucidation of Article 5 paragraph (20) letter a Bank Indonesia Regulation No. 20/6/ PBI/2018 concerning Electronic Money states that payment gateway operators are included in the group of front end providers. What is meant by front end operator is an operator that provides payment system services to users, goods and/or service providers (customer facing). Customer facing can be defined as a device or technology that interacts or communicates directly with consumers.

It is this front end group that will interact with consumers or business actors. In payment transactions, the payment gateway operator acts as a third party as an intermediary for forwarding data from consumers to business actors.

Payments made by consumers to business actors using a hosted payment gateway will be transferred from the business actor's page to the payment gateway provider's page to fill in credit card data. When the consumer will fill in the data on the page belonging to the payment gateway provider, the consumer must agree to the terms and conditions that are on the page belonging to the business actor. Approval of the terms and conditions can be done by clicking the "agree" button on the web page (clickwrap agreement) or directly continuing the payment process (browsewrap agreement). Agreements that occur between business actors and consumers in conducting payment transactions are an agreement with a browsewrap agreement form of agreement, although the consumer does not know the full contents of the agreement, the consumer knows that he will be redirected to a different page to fill out electronic transaction data so 
that the agreement results in the consumer being obedient to the conditions listed.

An example of a browser wrap agreement can be found on the Ebay Indonesia Online Store page, which is a business actor who works with the Paypal payment gateway. On that page, if we choose the payment option using a credit card, a notification will appear that the consumer will be redirected to another page to fill in data for further payment processing. This data entry page is a page belonging to the payment gateway provider, and the notification is information given to the consumer that the consumer will interact with the payment gateway provider through his page.

Quoted from the Paypal Policy website page, an example of an agreement made by Paypal is mentioned regarding the obligations that must be carried out by consumers in making payment transactions. One of the contents of the obligations contained in the agreement mentions payment instruments, one of which is a payment gateway. Payment gateway operators provide payment instruments in the form of a dashboard that makes it easy for consumers to fill in data and make payment transactions using credit cards. Regarding the provision of dashboards and payment mechanisms contained in the agreement between payment gateway providers and business actors, it is also necessary to look at the contents of the agreement.

In the agreement between the payment gateway provider and the merchant, for example Paypal's Terms of use, it is stated that the term "customer" is defined as a legal subject who purchases goods/and or services on the website of the user/business actor. The existence of this term can be said that consumers are parties involved in payment trans- actions using payment gateways contained in the agreement between payment gateway providers and business actors.

Article 1340 of the Civil Code contains the principle of privacy of contract which states that an agreement is valid only between the parties who made it. With these provisions, it can be said that the consumer is not a party involved in the agreement on the use of payment system services between the payment gateway operator and the business operator. Consumers as third parties who are not involved in the agreement do not have a commitment of involvement in the agreement for the use of payment system services between the payment gateway operator and the Entrepreneur. Article 1340 of the Civil Code has the same character as Article 1315 of the Civil Code, which both contain the basic element of privacy of contract where in Article 1315 of the Civil Code explains that the parties who make the agreement have the rights and obligations of an agreement made.

However, in Article 1340 of the Civil Code, the second paragraph contains an exception, namely in the phrase "other than in matters regulated in article 1317". Article 1317 of the Civil Code referred to as derden beding is an exception to the principle of privacy of contract allowing a person to enter into an agreement with another party for the benefit of a third party, not to burden him. The third party is required to state that it will exercise the right, and the party granting the right to the third party cannot withdraw it.

From the provisions and explanation of Article 1317 of the Civil Code above, the consumer as a third party cannot be bound by an agreement on the use of payment system services between the payment gateway operator and the merchant, nor is it a derden being. 
This is because in the process of filling in the data on the page belonging to the payment gateway operator, there is no form of agreement on the agreement between the payment gateway operator and the business actor. The agreement approved by the consumer is only the agreement contained on the home page of the Business Owner which is a standard provision on the payment mechanism in general in the Business Owner page and has no relationship with the agreement for the use of payment system services.

From the results of the research and the author's interview to, Bank Indonesia Lampung region, Lampung Consumer Protection Agency, Financial Services Authority can be concluded that the legal relationship between Payment Gateway Users and Payment Gateway Operators at Fintech Paypal Indonesia arises due to legislation, namely Bank Indonesia Regulation Number 18/14/PBI/2016 on the Conduct of Payment Transaction Processing, Article 1233 of the Civil Code states that each alliance is born either by approval or by law.

Legal relationships that arise due to provisions regarding the obligations of payment gateway operators as payment system service providers to consumers. Because the law regulates this, there is no specific time for the emergence of a legal relationship, in the sense that the legal relationship that arises between the payment gateway and the consumer can arise at any time. Regulations governing the relationship between payment gateways and consumers are contained in Article 25 of Bank Indonesia Regulation Number 18/14/ PBI/2016 on the Implementation of Payment Transaction Processing as mentioned in the role of payment gateway operators where the organizer must provide information payment instruments in electronic transactions to consumers and also ensure that there has been delivery of goods and/or services from business actors to consumers.

In providing services to consumers related to payment, the payment gateway operator is required to provide information to consumers that consumers are using the services of the payment gateway. In addition, the payment gateway operator must also provide information on the benefits, risks and consequences for consumers in accordance with Article 11 of Bank Indonesia Regulation Number 16/1/ PBI/2014 on Consumer Protection of Payment System Services. Judging from the regulations, it can be concluded that the position of the payment gateway operator to the consumer is a third party who is responsible for continuing the consumer information data that exists in the web browser belonging to the Business Actor to the Bank or Institution.

\section{Settlement of Disputes and Claims for Chargeback in Payment Gateway Transac- tion Activities at Fintech Paypal Indonesia}

The developing world economic system has encouraged activities in the world of industry and trade to be highly developed, both in the international and national scope. This is supported by the large variety of goods and/or services that enliven the trade market to meet the growing needs of human life. In addition, unlimited trade which is enforced almost all over the world fulfills the activities of trading in goods and/or services of a country so that the products offered are of a wider variety, Indonesia is no exception. This condition is also supported by the development of the world of information technology and telecommunications which is a means of expanding business transactions which are increasingly advanced 
as virtual markets. ${ }^{9}$ Online buying and selling transactions with payment via Paypal, take the form of electronic transactions or commonly known as e-commerce. Of course, in online buying and selling transactions, not everything goes as desired. There are many reasons for the risk of disputes arising, ranging from delivery delays, damaged goods, and transactions without authorization and do not rule out the possibility of fraud.

Based on the results of research and interviews with Mrs. Triani Susanti from Bank Indonesia Lampung Region, she explained that the legal provisions governing e-commerce activities in Indonesia are generally contained in the Civil Code, Law Number 19 of 2016 concerning Amendments to Laws. Law Number 11 of 2008 concerning Information and Electronic Transactions, Electronic Transactions and the Default Act, acts against the law or for reasons of consumer protection.

Information obtained from the Paypal.com website in Paypal's policy explains that what is listed in the Paypal account is a virtual account that provides transfer services and online payments. Paypal has a strong network and serves various financial transactions between countries, where all of these things have been done using electronic mail online, the existence of Paypal has changed the previous platform method, where previous money transfers were still made using paper in the form of checks and postal money orders, which in general will require a fairly long amount of time in its implementation, other online banking transactions that are only limited to transactions in one country, but Paypal now has a wide network and can be done even

\footnotetext{
9 Gunawan Widjaja and Kartini Muljadi, Perikatan Yang Lahir Dari Perjanjian (Jakarta: Raja Grafindo Persada, 2003).
}

between countries and within seconds can directly make transactions wherever they are.

This is the reason why many people use Paypal in the online business they manage, because Paypal makes it easy to send money and also provides convenience and security for online businesses wherever they are. Transactions using Paypal will run easily and very smoothly, as long as the user has a Paypal account that is connected to the business they run.

Information obtained from the Paypal.com website explains that there are many reasons for the risk of disputes arising in paypal, ranging from delays in delivery, damaged goods, and transactions without authorization. If there is a problem with the purchase, the paypal system provides services that can communicate directly with the seller by opening a dispute at the Paypal Dispute Resolution Center. There are 2 types of disputes:

1. Item Not Received - when you buy something, but don't receive it. (Usually Consumers are given a waiting time of at least 3 days from the transaction date so that the seller has enough time to send the goods.)

2. Items purchased are very different from the description - When receiving the goods, they are very different from the initial description from the seller. (Consumers can make returns but must pay the cost of returning goods, if they meet the requirements for the Return Fees on the responsibility of paypal.

The first step when experiencing a dispute in a paypal transaction is to file a dispute within 180 days of payment and try to resolve the issue with the seller through the Dispute Resolution process in the Resolution Center. If you are unable to resolve the dispute, you can escalate it into a claim to Paypal within 20 
days from the date the dispute was filed. After that, the dispute will be automatically closed and the customer will no longer be eligible for Paypal Buyer Protection. in the dispute resolution process can provide additional information or evidence to help resolve claims.

Figure 1: Chart of the stages of dispute resolution
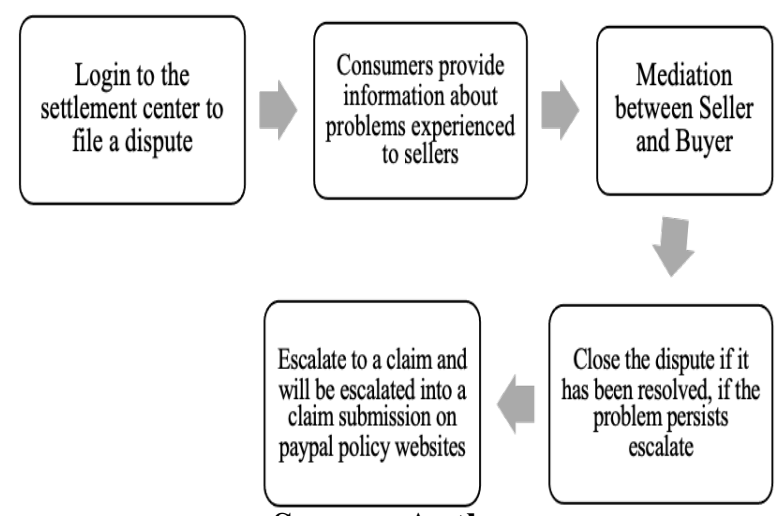

Source: Author

Information obtained from the Paypal. com website, the paypal policy explains that in the Paypal system, if the dispute cannot be resolved, the paypal system will check it by escalating it into a claim. Claims are requests for compensation from consumers, to business actors in accordance with the insured loss, usually deciding the outcome of the claim within 30 days or less. Escalate to a claim within 20 days from the date the dispute was filed. The dispute will be closed automatically if it is not escalated into a claim within 20 days. Disputes that have been closed cannot be reopened or escalated into claims. In online buying and selling transactions in the paypal system, if you buy goods on e-Bay but do not receive them or receive goods that are different from the information provided, the paypal system provides protection. Paypal Buyer Protection will protect eligible transactions for paid purchases plus initial shipping costs. Certain purchases such as vehicles in the Vehicles category, capital equipment in the Business \& Industry category and Real Estate are not eligible for Paypal Buyer Protection.

In addition to being able to make a claim, the paypal system can also make a chargeback, which occurs when the consumer does not agree with the credit card bill and asks the credit card company to return the funds. When a consumer submits a chargeback to a credit card issuer, this means that they dispute the bill and ask the card issuer to return the funds. Generally it is explained in the PayPal Fintech Policy Center explaining Usually Consumers file a chargeback because they:

a. Did not receive the goods.

b. Receiving damaged or defective goods.

c. Does not recognize credit card charges.

d. Charged more than once for something.

e. Not authorizing payment.

Figure 2: Stage Chart Image To make a chargeback on paypal

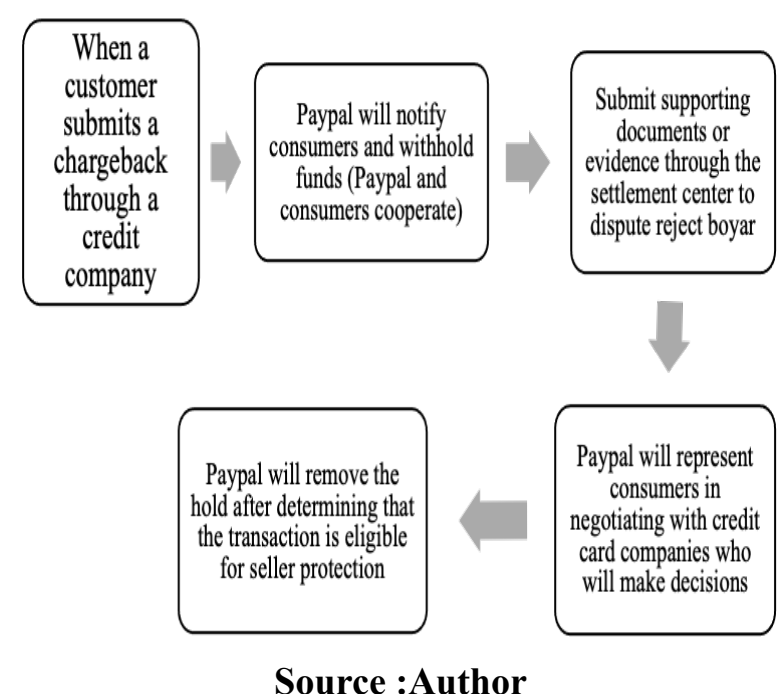

Information obtained from the Paypal.com website explains that the Paypal system when consumers receive a chargeback, the paypal system will notify the consumer, if the consumer agrees the chargeback will be valid, and the Paypal party will dispute it by provid- 
ing information about the transaction at the Settlement Center.

The chargeback is not the same as Paypal claims, the chargeback process is done outside of Paypal, between the card issuer and the card owner. In disputes over chargebacks, the final decision is made by the card issuer. Paypal charges the seller a fee when the buyer submits a chargeback to his credit card issuer. If the transaction is covered by the Seller Protection Policy, Paypal will cover the chargeback amount and waive any chargeback fees.

A chargeback is filed when a consumer contacts thex issuing bank to request a payment reversal. Most of these chargebacks can be avoided. When consumers know the proper procedures, the less likely they are to run into problems that could result in chargebacks. As a consumer partner, paypal is ready

Table 1 to help resolve unwarranted chargebacks, and with the Seller Protection program, eligible consumer payments will be protected from fraudulent transactions and chargebacks for items not received.

Based on the results of research and interviews conducted by the author with Bank Indonesia, the Financial Services Authority and the Consumer Protection Agency, that in the process of resolving disputes, Indonesian law regulates provisions regarding Electronic Transactions so that if a consumer or business actor from Indonesia occurs in a dispute, they can comply with the existing legal provisions. and their rights/obligations will be protected by applicable law, these are the legal provisions governing them and the authors conclude and analyze them in the table:
Laws governing consumer protection in electronic transactions.

Consumer Protection Law Number 8 of 1999

Analysis

Consumer Legal Protection in Electronic Transactions in the Consumer Protection Act is all efforts that ensure legal certainty, provide protection to consumers. However, it is possible for business actors who have bad intentions towards consumers by overriding consumer rights as regulated in Article 4 and Article 18 of the Consumer Protection Law.

Law Number 19 of 2016 concerning Amendments to Law Number 11 of 2008 concerning Information and Electronic Transactions, Electronic Transactions.
If the business actor fulfills his responsibilities as regulated in Article 9 of the ITE Law concerning contract liability and product liability and Article 17 paragraph (2) of the ITE Law concerning the principles of responsibility, namely responsibility for mistakes, responsibility for negligence and the principle of responsibility. without error. The validity of an electronic contract is considered valid if it uses an electronic system in accordance with applicable laws and regulations and the electronic information is in written or original form where the information contained therein can be guaranteed to be intact, accounted for, accessed, displayed, so as to explain a situation. 


\begin{abstract}
Bank Indonesia Regulation Number 19/12/ This Bank Indonesia Regulation and Bank Indonesia $\mathrm{PBI} / 2017$ concerning the implementation of Circular Letter regarding electronic money regulates financial technology the terms and procedures for the parties in electronic money for the smooth operation of electronic money and the protection of cardholders. This is regulated in relation to the supervision of the implementation of electronic money activities and is a form of protection for e-money card holders.
\end{abstract}

Financial Services Authority Regulation Number 13/POJK.02/2018 Concerning Digital Financial Innovation in the Financial Services Sector
Consumer Protection is the protection of Consumers with the scope of behavior of Financial Services Business Actors. Consumers are parties who place their funds and/or take advantage of the services available at Financial Services Institutions, including customers in Banking, investors in the Capital Market, policyholders in insurance, and participants in Pension Funds, based on the legislation in the financial services sector .

Legal protection is to provide protection for human rights that are harmed by others and this protection is given to the community so that they can enjoy all the rights granted by law. If the consumer is the community, it means that protecting consumers means protecting the community. The law against Fintech consumers is the protection of the security of their personal data.

The existence of OJK as a supervisory agency in the financial services sector is expected to be able to protect consumers from PUJK which is considered to be detrimental to the interests of consumers, in this case Fintech consumers. OJK as an institution that has the authority to oversee business activities in the financial services sector, must be able to protect consumers using financial services who place their funds and/or take advantage of the services available at financial service institutions.
From the law that regulates online transactions, everything benefits consumers and consumers must remain careful in using electronics to carry out all activities in online transactions.

Until now, the absence of comprehensive regulations in the form of laws that regulate activities in online buying and selling transactions has resulted in problems that arise in electronic transaction activities which are currently constrained in terms of fraud and crime in the internet world. Online buying and selling transactions across national borders are a necessity for business actors to develop their business wings which demand regulations on these conditions from the government and the competent authorities as an effort to advance the economy as well as a form of attention to business actors and consumers in making buying and selling 
transactions. by online.

\section{CONCLUSION}

Based on the results of research and discussion regarding the analysis of dispute resolution and chargeback claims in Payment gateway transactions on fintech paypal Indonesia. So the author can draw the following conclusions:

1. Legal Relationship between Payment Gateway Users and Payment Gateway Providers At Fintech Paypal Indonesia is where the parties involved in the electronic payment system include consumers, business actors, acquirers, issuers and payment gateway providers. legal relationships that arise between consumers, business actors, acquirers, issuers and payment gateway operators are born from agreements made by the parties. However, consumers and payment gateway providers have a legal relationship created by the obligations and responsibilities of payment gateway operators as regulated in regulations.

2. In transactions using Paypal, of course, there are many reasons for the risk of disputes arising, ranging from delays in delivery, damaged goods, and transactions without authorization. If there are problems with purchases, Dispute Settlement and Claims for Chargeback in Payment Gateway Transaction activities on Fintech Paypal where the paypal system provides services, you can communicate directly with the seller by opening a dispute at the Paypal Dispute Settlement Center. If it is not completed in following the policies provided by paypal services, consumers or business actors can ask for recommendations to mediate to the paypal service center but if they are not finished, business actors and consumers can resolve disputes through litigation, which usually business actors are subject to the applicable law. applies where the consumer is a national, In the Dispute Resolution Process Indonesian Law regulates provisions regarding Electronic Transactions so that if a consumer or business actor from Indonesia occurs in a dispute, they can comply with the existing legal provisions and their rights/obligations will be protected by this applicable law.

\section{BIBLIOGRAPHY}

\section{Books}

Ardhiwisastra, Yudha Bhakti. Penafsiran Dan Konstruksi Hukum. Bandung: Alumni, 2000.

Muhammad, Abdulkadir. Hukum Perdata Indonesia. Bandung: Citra Aditya Bakti, 2017.

Widjaja, Gunawan, and Kartini Muljadi. Perikatan Yang Lahir Dari Perjanjian. Jakarta: Raja Grafindo Persada, 2003.

\section{Journal}

Ningsih, Ayup Suran. "Legal Review of Financial Technology Peer To Peer Lending Based on Indonesian Collateral Law Perspective." Substantive Justice International JournalofLaw3, no. 2(2020): 109-124. https://substantivejustice.id/ index.php/sucila/article/view/73.

Rosul, Chaidar Shofi. "Hubungan Hukum Penyelenggara Payment Gateway Dan Konsumen Dalam Sistem Pembayaran Elektronik." Jurist-Diction 2, no. 5 (2019): 1611-1630. https://e-journal.unair.ac.id/ JD/article/view/15220.

Surohman, Sopian Aji, Rousyati Rousyati, and Fanny Fatma Wati. "Analisa Sentimen Terhadap Review Fintech Dengan Metode 
Naive Bayes Classifier Dan K- Nearest Neighbor." EVOLUSI: Jurnal Sains dan Manajemen 8, no. 1 (2020): 93-105. https://ejournal.bsi.ac.id/ejurnal/index. php/evolusi/article/view/7535.

Suryansyah. "Legal Protection on Intellectual Property Rights in the Development of Creative Economy in Mamuju Regency." Substantive Justice International Journal of Law 2, no. 1 (2019): 54-70. https:// substantivejustice.id/index.php/sucila/ article/view/30.

\section{Thesis}

Rahardika, Prakas Dwi. "Implementasi Sistem Pembayaran Dengan Payment Gateway Pada Pemesanan Tour \& Transport (Studi Kasus PT.Hanoman Pandu Wisata).” Universitas Teknologi Yogyakarta, 2020. Utama, Sri Yunengsih. "Perlindungan Hukum Terhadap Pemegang Kartu Kredit Sebagai Akibat Penyalahgunaan Kartu Kredit Dalam Transaksi Perdagangan.” Universitas Pasundan, 2013. http:// repository.unpas.ac.id/1712/.

\section{Law and Regulation}

Bank Indonesia Regulation (PBI) Number 19/12/PBI/2017 concerning the Implementation of Financial Technology
Bank Indonesia Circular Letter Regulation No.11/10/DASP concerning Implementation of Card-Based Payment Instrument Activities

Bank Indonesia Regulation No. 20/6/ PBI/2018 regarding Electronic Money

Bank Indonesia Regulation Number 16/1/ PBI/2014 concerning Consumer Protection of Payment System Services

Civil Code (burgelijk wetboek)

Commercial Law (wetboek van kophandel)

Financial Services Authority Regulation Number 13/POJK.02/2018 Regarding Digital Financial Innovation in the Financial Services Sector

Law Number 10 of 1998 concerning Banking Law Number 8 of 1999 concerning Consumer Protection

Law No. 23 of 1999 concerning Bank Indonesia

Law Number 19 of 2016 concerning Amendments to Law Number 11 of 2008 concerning Information and Electronic Transactions

The 1945 Constitution of the Republic of Indonesia 